\title{
A Galvanic Cell With a Low Emf-Temperature Coefficient
}

\author{
Gerald N. Roberts* and Walter J. Hamer
}

Institute for Basic Standards, National Bureau of Standards, Washington, D.C. 20234

(January 24, 1968)

This paper presents data on a modified cadmium sulfate saturated standard cell of the Vosburgh type in which a tertiary amalgam containing 11.2 percent bismuth and 8.4 percent cadmium is used as anode and the double salt, $\mathrm{CdSO}_{4} \cdot \mathrm{Na}_{2} \mathrm{SO}_{4} \cdot 2 \mathrm{H}_{2} \mathrm{O}$ is added to the usual $\mathrm{CdSO}_{4}$ electrolyte in an amount more than sufficient to saturate the solution with the double salt. Crystals of $\mathrm{CdSO}_{4} \cdot \mathrm{Na}_{2} \mathrm{SO}_{4} \cdot 2 \mathrm{H}_{2} \mathrm{O}$ are placed over the surface of both electrodes. The emf of the cell, as a function of temperature, is given by

$$
E(\text { in volts })=1.018243+3.0956 \times 10^{-5} t-8.559 \times 10^{-7} t^{2}+1.3534 \times 10^{-8} t^{3} .
$$

At $25{ }^{\circ} \mathrm{C}$ the cell has an emf-temperature coefficient of $+13.5 \mu \mathrm{V} /{ }^{\circ} \mathrm{C}$ while the conventional saturated cadmium sulfate cell has a $d E / d T$ of $-49.4 \mu \mathrm{V} /{ }^{\circ} \mathrm{C}$. Data on the emf-temperature hysteresis of the cell on cooling and on heating are also given in graphical form. Data on the changes in Gibbs energy, enthalpy, entropy, and heat capacity for the cell reaction are given for the temperature range of 5 to $40^{\circ} \mathrm{C}$.

Key Words: Double salt; cell with low temperature coefficient; galvanic cells; standard cells.

\section{Introduction}

Conventional cadmium sulfate standard cells are of two general types: saturated and unsaturated where these terms refer to the state of the electrolytic solution used in the cell. These cells differ in two regards: the saturated type has the greater emf stability, and therefore the longer life; it also has the higher emf-temperature coefficient, $-49.4 \mu \mathrm{V} /{ }^{\circ} \mathrm{C}$ at $25^{\circ} \mathrm{C}$. The unsaturated cell decreases in emf, on the average, at the rate of 20 $\mu \mathrm{V}$ per year and has an emf-temperature coefficient of the order of only a few microvolts per degree Celsius at room temperature [1]. ${ }^{1}$

It would be highly desirable if a cell could be constructed which had the better feature of each of these two types, i.e., emf stability and low variation in emf with temperature. Vosburgh and co-workers [2, 3, 4, 5] have investigated this problem. Their general approach was to modify the conventional cadmium sulfate cell, ${ }^{2}$ either by addition of a third metal to the cadmium

\begin{tabular}{|c|c|c|}
\hline $\begin{array}{c}(-) \mathrm{Cd}, \mathrm{Bi}, \\
\mathrm{Hg}(3 \mathrm{p})\end{array}$ & $\begin{aligned} & \mathrm{CdSO}_{4} \cdot 8 / 3 \mathrm{H}_{2} \mathrm{O}(\mathrm{c}) \\
& \mathrm{CdSO}_{4} \cdot \mathrm{Na}_{2} \mathrm{SO} \cdot 2 \mathrm{H}_{2} \mathrm{O}(\mathrm{c})\end{aligned}$ & $\begin{array}{l}\text { sat aq sol of the } \\
\text { two salts in } \\
0.038 \mathrm{~N} \mathrm{H}_{2} \mathrm{SO}_{4}\end{array}$ \\
\hline
\end{tabular}

*Presently, Research Associate in Chemistry, The American University, Washington, D.C. 20016.

' Figures in brackets indicate the literature references at the end of this paper.

2 Also referred to as the Weston cell after Edward Weston who invented the cell in 1892. amalgam or the addition of another component to the electrolyte, or both. Thus, Vosburgh, Guagenty, and Clayton [3] added bismuth to the amalgam (11.1\% $\mathrm{Bi}, 8.9 \% \mathrm{Cd}, 80 \% \mathrm{Hg}$ ) and the double salt, $\mathrm{CdSO}_{4}$. $\mathrm{Na}_{2} \mathrm{SO}_{4} \cdot 2 \mathrm{H}_{2} \mathrm{O}$ to the saturated solution of $\mathrm{CdSO}_{4}$ in sufficient quantity to make the solution also saturated in the double salt. They also added crystals of the double salt at both electrodes to assure saturation of the solution. In making the solution they used either 0.015 molar sulfuric acid or 0.1 molar acetic acid as solvent.

The present paper describes a further study of this type of cell. The cell was slightly modified by adding a higher concentration of sulfuric acid so that the acidity of the saturated electrolyte solution was 0.038 normal. Also the composition of the tertiary amalgam was slightly different and contained 11.16 percent $\mathrm{Bi}$, 8.41 percent $\mathrm{Cd}$, and 80.43 percent $\mathrm{Hg}$. Various thermodynamic data for the cell reaction are also presented.

The cell may be represented by:

$$
\left|\begin{array}{c}
\mathrm{CdSO}_{4} \cdot 8 / 3 \mathrm{H}_{2} \mathrm{O}(\mathrm{c}), \\
\mathrm{CdSO}_{4} \cdot \mathrm{Na}_{2} \mathrm{SO}_{4} \cdot 2 \mathrm{H}_{2} \mathrm{O}(\mathrm{c})
\end{array}\right| \mathrm{Hg}_{2} \mathrm{SO}_{4}(\mathrm{~s}) \mid \mathrm{Hg}(\mathrm{l})(+)
$$

where the vertical lines indicate the interface of two distinct phases (the amalgam consists of 3 phases but vertical lines are not used in designating it). 


\section{Materials and Procedures}

The materials employed in making the cells and descriptions of how they were purified or prepared for use follow:

Mercury: Triply distilled mercury was used at the cathode and in making the amalgam for the anode.

Cadmium: Redistilled spectrograde cadmium was used. Bismuth: Cerro De Pasco high grade bismuth having a stated purity of 99.9992 percent was used in making the bismuth amalgam.

Sulfuric acid: Reagent grade sulfuric acid was distilled twice in an all Pyrex still. Only the middle fractions of the distillate were used.

Water: Doubly distilled conductivity water having a conductivity less than $1 \times 10^{-6} \Omega^{-1} \mathrm{~cm}^{-1}$ was used in making the solutions of cadmium sulfate and the double salt, $\mathrm{CdSO}_{4} \cdot \mathrm{Na}_{2} \mathrm{SO}_{4} \cdot 2 \mathrm{H}_{2} \mathrm{O}$.

Cadmium sulfate: Reagent grade cadmium sulfate was recrystallized two times from an aqueous solution. Spectrographic analysis showed that the recrystallized salt was of high purity.

Sodium sulfate: Reagent grade sodium sulfate was reçrystallized two times from an aqueous solution. Spectrographic analysis showed that the recrystallized salt was of high purity.

Double salt: The double salt, $\mathrm{CdSO}_{4} \cdot \mathrm{Na}_{2} \mathrm{SO}_{4} \cdot 2 \mathrm{H}_{2} \mathrm{O}$ was prepared by mixing aqueous solutions of the two component salts. Solubility data [6] indicated that it is possible to produce both the double salt and an excess of $\mathrm{CdSO}_{4} \cdot 8 / 3 \mathrm{H}_{2} \mathrm{O}$ by mixing at $20{ }^{\circ} \mathrm{C} 40.26 \mathrm{~g}$ of $\mathrm{CdSO}_{4}$ dissolved in $50 \mathrm{ml}$ of water with $5.16 \mathrm{~g}$ of $\mathrm{Na}_{2} \mathrm{SO}_{4}$ in a like volume of water. This procedure was followed and the resulting saturated solution was allowed to concentrate by evaporation. The salt thus produced was analyzed and found to have the two component salts in the correct stoichiometric ratio. Amalgam: The amalgam was prepared by heating the required amounts of the three metals together in a porcelain casserole and was added, while homogeneous, to the cells using an electrically heated funnel. Mercurous sulfate: The mercurous sulfate was prepared by dc electrolysis using the method of Wolff and $\mathrm{W}$ aters [7] or Hulett [8]. It was thoroughly washed with several portions of the same cadmium sulfate solution which was used in the cell.

Cell blanks and platinum cell-leads: These were identical to those described in reference [1].

The cell blanks were washed, filled, and sealed in the manner described in reference [1] for conventional $\mathrm{CdSO}_{4}$ cells and the assembled cells were then placed in a constant temperature oil bath which could be operated at any temperature from 0 to $100{ }^{\circ} \mathrm{C}$. The cells were supported in the bath on wooden racks with copper-mercury terminals as described in reference [1]. The temperature of the bath was controlled to within $0.001{ }^{\circ} \mathrm{C}$ above $15{ }^{\circ} \mathrm{C}$ and to within about $0.005{ }^{\circ} \mathrm{C}$ below $15{ }^{\circ} \mathrm{C}$. The emfs of the cells were measured to $1 \mu \mathrm{V}$ using potentiometers of high sensitivity.

In all, seventeen cells were made. Of these eleven showed good behavior whereas six were erratic in their performance for no apparent reason; data on the latter are not included in this paper.

\section{Results}

The average results obtained on the eleven cells which showed good performance are given in table 1 for temperatures from 5 to $40{ }^{\circ} \mathrm{C}$, in the sequence in which the emfs were measured. Two sets of results are given for $25^{\circ} \mathrm{C}$ and the averages of the two sets agree within $6 \mu \mathrm{V}$. Variations of the individual emfs about the average is indicated by the standard deviation, $s$, and the standard deviation of the mean emf is given by $s_{m}$ listed at the bottom of table 1 . These deviations increased as the temperature of the cells was lowered; thus, emf reproducibility is less marked at the lower temperatures. At $40{ }^{\circ} \mathrm{C}$ the emfs fall into two groups, one averaging $1.018976 \mathrm{~V}$ and the other $1.018837 \mathrm{~V}$. This difference may be explained either on a phase transition or the appearance of a new salt phase; further work is required to decide this. Those cells with the higher emf, in either case, would correspond to cells with the salts in a metastable state. The higher emf was selected for preparations of figures 1 and 2.

TABLE 1. Average emfs of Bi-Cd amalgam cell from 5 to $40^{\circ} \mathrm{C}$

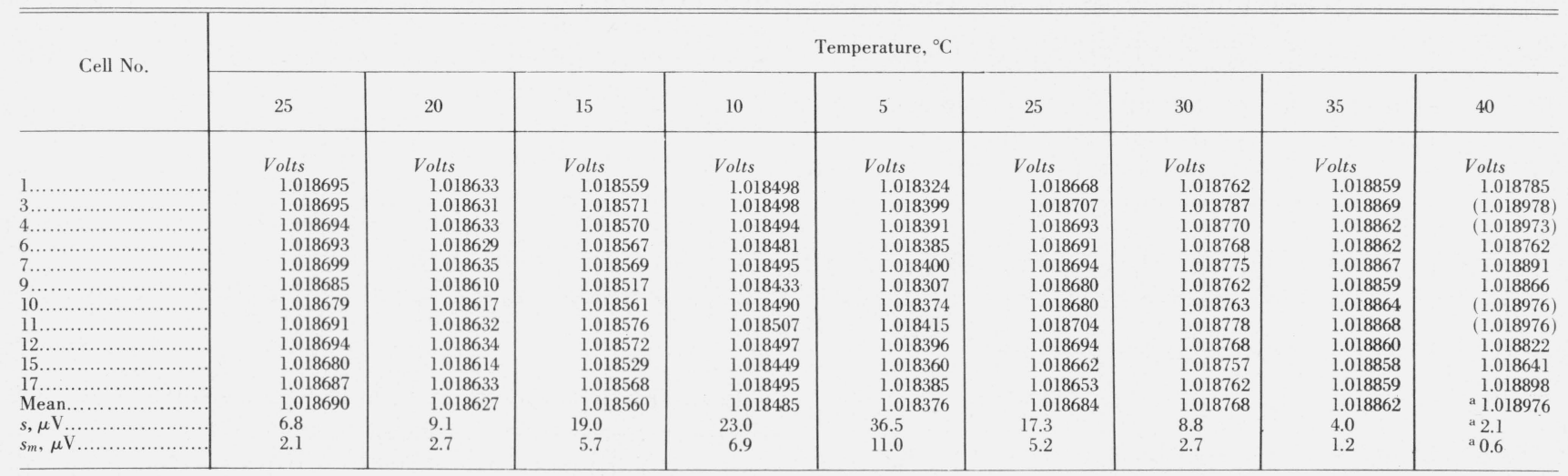

a Mean of the values in parentheses. 


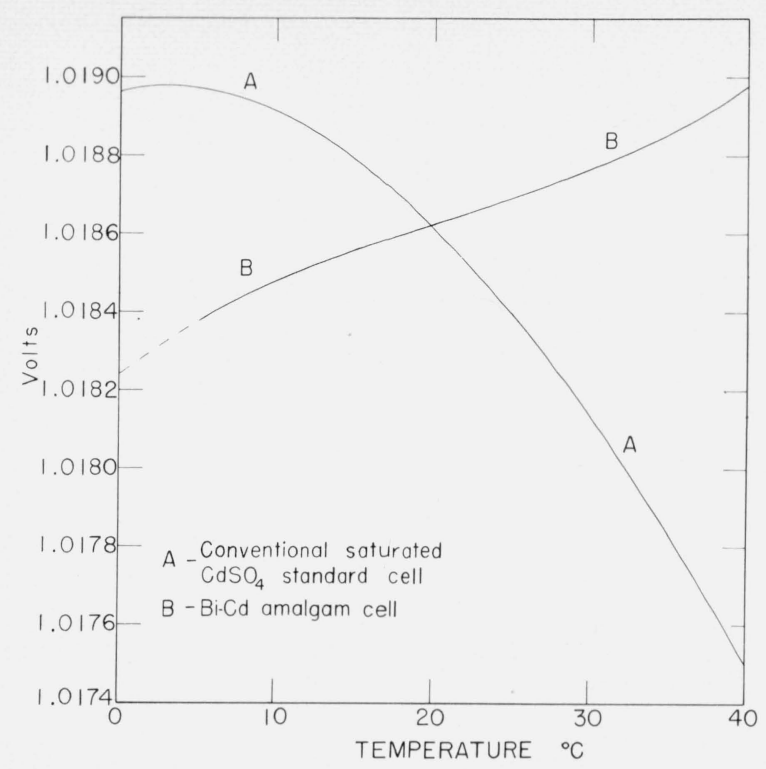

FIGURE 1. The variation of the emf of the Bi-Cd amalgam cell and the conventional saturated $\mathrm{CdSO}_{4}$ standard cell with temperature.

The emfs are shown as a function of temperature in figure 1 and compared with those for the conventional saturated cadmium sulfate cell. The value at $0{ }^{\circ} \mathrm{C}$ (dotted extension) was obtained from eq (1), below. It is evident that the two types of cells show opposite behavior with changes in temperature. The conventional type shows a decrease in emf while the Bi-Cd type described herein shows an increase in emf as the temperature of the cell is raised. The emf-temperature coefficients of the two types of cells are shown in figure 2 . The value at $0{ }^{\circ} \mathrm{C}$ (dotted extension) was obtained from equation 1 , below. It is evident that the new type of cell, above $5{ }^{\circ} \mathrm{C}$, has a lower emftemperature coefficient and of opposite sign than the conventional type. For example, at $25{ }^{\circ} \mathrm{C}$, the new type has a $d E / d T$ of $+13.5 \mu \mathrm{V} /{ }^{\circ} \mathrm{C}$ whereas the conventional type has a $d E / d T$ of $-49.4 \mu \mathrm{V} /{ }^{\circ} \mathrm{C}$. This value for $d E / d T$ at $25^{\circ} \mathrm{C}$ agrees closely with that observed by Vosburgh et al. [3].

The mean emfs of table 1 were fitted by the method of least squares using linear, quadratic, and cubic relations with temperature. As would be expected from the form of curve shown in figure 1 , a cubic equation gave the best fit; the relation obtained is:

$E($ in volts $)=1.018243+3.0956 \times 10^{-5} t-8.559$

$$
\times 10^{-7} t^{2}+1.3534 \times 10^{-8} t^{3} .
$$

The overall chemical reaction for the cell is given by: $[x \mathrm{Cd}, y \mathrm{Bi}, z \mathrm{Hg}](3 p)+\mathrm{Hg}_{2} \mathrm{SO}_{4}(\mathrm{~s})+\frac{8 / 3}{m-8 / 3}\left(\mathrm{CdSO}_{4}\right.$ - $m \mathrm{H}_{2} \mathrm{O}$ ) (sat with $\mathrm{CdSO}_{4} \cdot 8 / 3 \mathrm{H}_{2} \mathrm{O}$ and $\mathrm{CdSO}_{4} \cdot \mathrm{Na}_{2} \mathrm{SO}_{4}$ $\left.\cdot 2 \mathrm{H}_{2} \mathrm{O}\right)=\frac{m}{m-8 / 3}\left(\mathrm{CdSO}_{4} \cdot 8 / 3 \mathrm{H}_{2} \mathrm{O}\right)(\mathrm{c})\left(\right.$ sat with $\mathrm{CdSO}_{4}$ - $8 / 3 \mathrm{H}_{2} \mathrm{O}$ and $\left.\mathrm{CdSO}_{4} \cdot \mathrm{NaSO}_{4} \cdot 2 \mathrm{H}_{2} \mathrm{O}\right)+2 \mathrm{Hg}(\mathrm{l})+$ $[(x-1) \mathrm{Cd}, y \mathrm{Bi}, z \mathrm{Hg}](3 \mathrm{p})$ where $x$ moles of $\mathrm{Cd}$ are

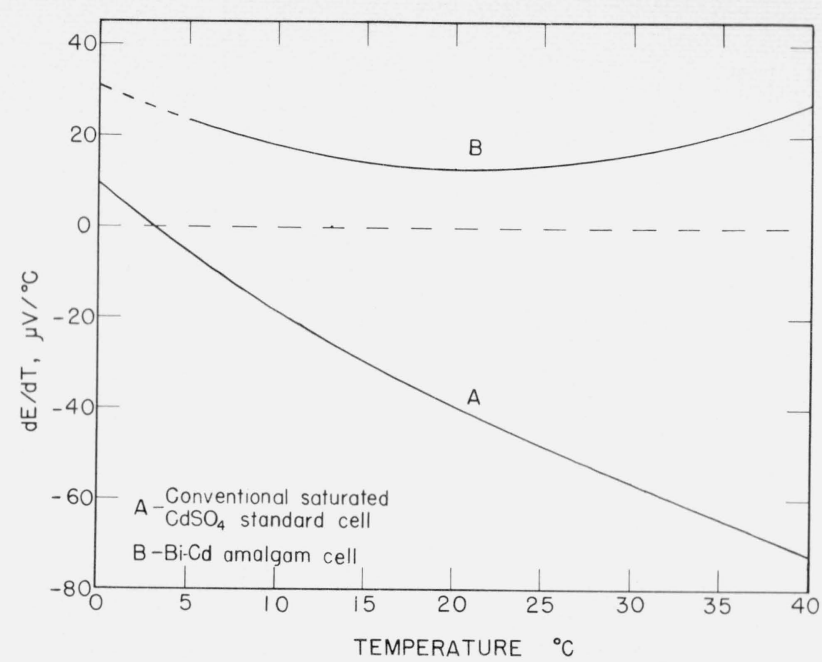

FIGURE 2. The emf-temperature coefficient in microvolts per degree Celsius for the Bi-Cd amalgam cell and the conventional saturated $\mathrm{CdSO}_{4}$ standard cell at various temperatures.

associated with $y$ moles of $\mathrm{Bi}$ and $z$ moles $\mathrm{Hg}$ and $m$ is the number of moles of water associated with 1 mole of $\mathrm{CdSO}_{4}$ in the saturated solution. The changes in Gibbs energy (free energy), enthalpy, entropy, and heat capacity for the cell reaction are given, respectively, by: $\Delta G=-n F E ; \Delta H=-n F E+n F T(d E / d T): \Delta S=n F$ $(d E / d T) ; \quad$ and $\quad \Delta C_{p}=[d(\Delta H) / d T]=n F T\left(d^{2} E / d T^{2}\right)$ where $F$ is the Faraday and $n$ is the number of equivalents involved in the cell reaction; in the present case $n=2$. The value of $F$ is $96487 \mathrm{C} / \mathrm{g}$ equivalent on the ${ }^{12} \mathrm{C}$ scale of atomic weights $[10,11]$; thus if $E$ is expressed in volts, $\Delta G$ is given in volt coulombs per gram equivalent or in joules per gram equivalent. Values of $\Delta G, \Delta H, \Delta S$, and $\Delta C_{p}$ are given in table 2.

The emf-temperature hysteresis of the cell was also determined on cooling and on heating; these effects are shown in figures 3 and 4 where $\alpha$ (the ordinate) is the difference in $\mu \mathrm{V}$ from $1.018 \mathrm{~V}$. On cooling the emf first changes markedly in the opposite direction to the final value, i.e., the emf first increases and then decreases to the equilibrium value (a slight over

TABLE 2. Thermodynamic data for the reaction in the galvanic cell described herein

\begin{tabular}{|c|c|c|c|c|}
\hline \multicolumn{5}{|c|}{ Changes $^{\text {a }}$ in } \\
\hline Temperature & Gibbs energy & Enthalpy & Entropy & Heat capacity \\
\hline${ }^{\circ} \mathrm{C}$ & $\Delta G$ & $\Delta H$ & $\Delta S$ & $\Delta C_{p}$ \\
\hline $\begin{array}{c}\mathrm{b}(0) \\
5 \\
10 \\
15 \\
20 \\
25 \\
30 \\
35 \\
40\end{array}$ & $\begin{array}{c}J \mathrm{~mol}^{-1} \\
(-196,494) \\
-196,520 \\
-196,540 \\
-196,556 \\
-196,569 \\
-196,581 \\
-196,596 \\
-196,613 \\
-196,636\end{array}$ & $\begin{array}{c}J \mathrm{~mol}^{-1} \\
(-194,863) \\
-195,263 \\
-195,563 \\
-195,755 \\
-195,836 \\
-195,803 \\
-195,650 \\
-195,377 \\
-194,976\end{array}$ & $\begin{array}{cc}J \mathrm{~mol}^{-1} \quad \text { deg }^{-1} \\
(5.97) \\
4.52 \\
3.45 \\
2.78 \\
2.50 \\
2.61 \\
3.12 \\
4.01 \\
5.30\end{array}$ & $\begin{array}{cc}J \mathrm{~mol}^{-1} \quad \mathrm{deg}^{-1} \\
& (-90.2) \\
& -70.1 \\
& -49.2 \\
& -27.5 \\
& -5.0 \\
& +18.3 \\
& +42.4 \\
& +67.2 \\
& +92.8\end{array}$ \\
\hline
\end{tabular}

a These may be converted to the thermochemical calorie (defined) by the relation 1 thermochemical calorie (defined) $=4.1840 \mathrm{~V}[9]$.

${ }^{b} V$ alues at $0^{\circ} \mathrm{C}$ obtained from $E$ and $d E / d T$ given by eq (1). 


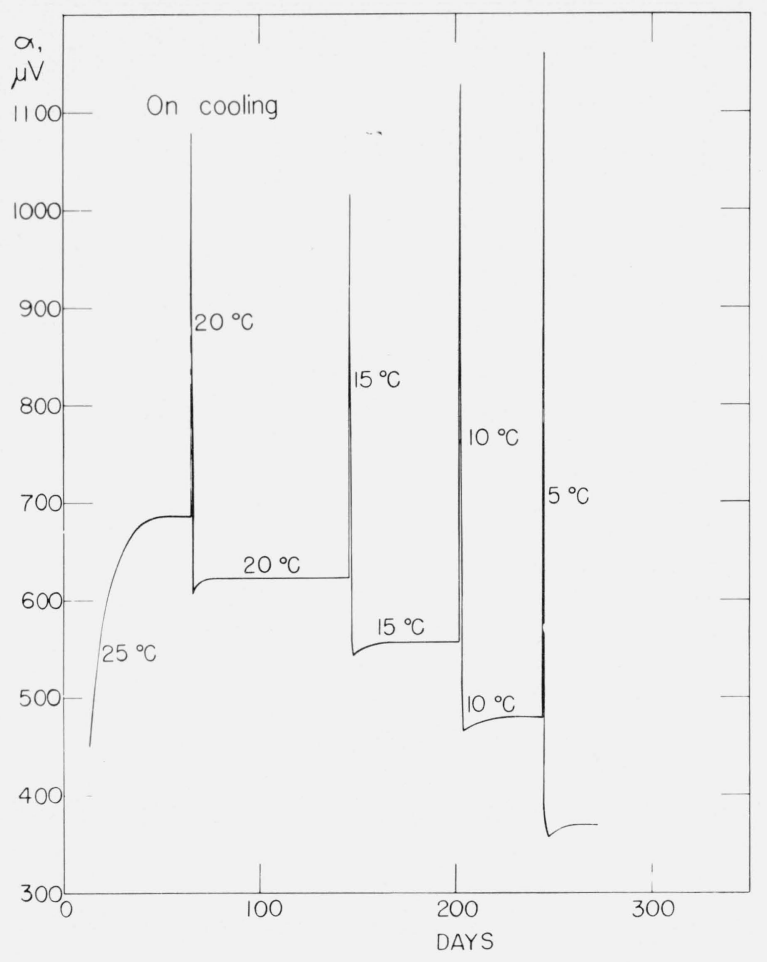

FIGURE 3. Emf-temperature hysteresis of the Bi-Cd amalgam cell on cooling, $\alpha$ defined in text.

decrease is also noted at all temperatures). On heating the opposite effect is noted; the emf first decreases and then increases to the equilibrium value. The initial changes in emf in the direction opposite to that expected are called emf-temperature hysteresis. Although these hysteresis effects persist for less than a day, they are more marked than those observed for the conventional saturated cadmium sulfate cell [12], and more work would be required to ascertain if means could be found to reduce the magnitude and extent of the hysteresis.

\section{Conclusions}

The Bi-Cd amalgam cell described in this paper has a much lower emf-temperature coefficient, but of opposite sign, than the conventional saturated cadmium sulfate standard cell currently used as a standard of electromotive force. Also, the cell's shortterm stability exceeds that shown by unsaturated $\mathrm{CdSO}_{4}$ standard cells. The average emf of the first and second measurements at $25{ }^{\circ} \mathrm{C}$, which were 300 days apart, agreed to $6 \mu \mathrm{V}$; the unsaturated $\mathrm{CdSO}_{4}$ cell, on the other hand, decreases in emf at an average rate of $20 \mu \mathrm{V}$ per year. Cells of this type appear also to have the long-term emf stability to within $10 \mu \mathrm{V}$ [13].

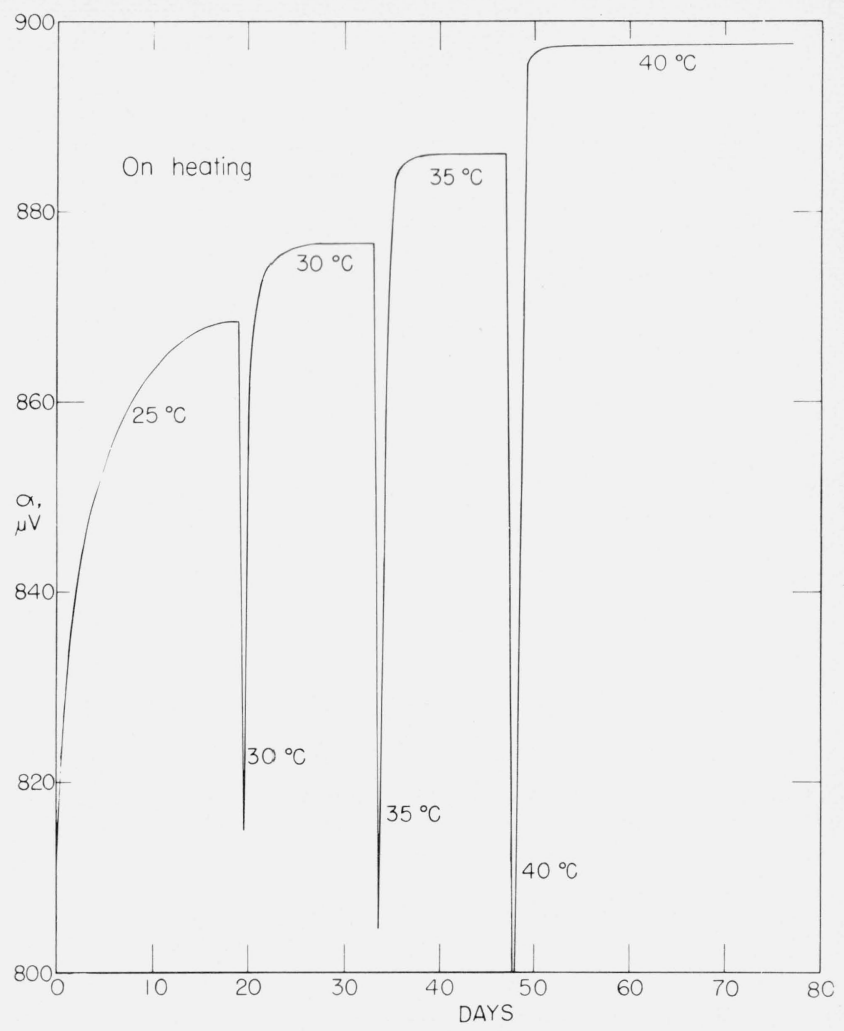

FIGURE 4. Emf-temperature hysteresis of the Bi-Cd amalgam cell on heating, $\alpha$ defined in text.

The authors are indebted to Harold J. DeWane for writing the computer program, to Virginia C. Stewart for spectrographic analysis, to T. C. Rains for analysis of the double salt, and to Anne M. O'Toole for help in making some of the emf measurements.

\section{References}

[1] Hamer, W. J., Standard Cells, Their Construction, Maintenance, and Characteristics, NBS Mono. 84, 1965.

[2] Vosburgh, W. C., J. Am. Chem. Soc. 47, 2531 (1925).

[3] Vosburgh, W. C., Guagenty, M., and Clayton, W. J., J. Am. Chem. Soc. 59, 1256 (1937).

[4] Vosburgh, W. C., and Parks, H. C., J. Am. Chem. Soc. 61, 652 (1939).

[5] Vosburgh, W. C., Derr, P. F., Cooper, G. R., and Pettengill, B., J. Am. Chem. Soc. 61, 2687 (1939).

[6] Koppel, J., and Gumperz, A., Z. physik. chem. 52, 413 (1905).

[7] Wolff, F. A., and Waters, C. E., BS Bull. 4, 1 (1907).

[8] Hulett, G. A., Phys. Rev. 32, 257 (1911).

[9] New Values for the Physical Constants-Recommended by NAS-NRC, NBS Tech. News Bull. 47, No. 10, 175 (1963); Consistent Set of Physical Constants Proposed, Chem. and Eng. News 41, No. 46, 43 (Nov. 18, 1963).

[10] Craig, D. N., Hoffman, J. I., Law, C. A., and Hamer, W. J., J. Res. NBS (Phys. and Chem.) 64A, 381 (1960).

[11] Hamer, W. J., and Craig, D. N., J. Electrochem. Soc. 111, 1434 (1964).

[12] Eppley, M., and Vincent, G. D., Electrochemical Constants, NBS Circ. 524, ch. 10, 1953.

[13] Vosburgh, W. C., and Bates, R. G., J. Electrochem. Soc. 111, 997 (1964).

(Paper 72A-4-506) 